\title{
Model of Efficient Buildings on Electrical Consumption towards Location in Simpang Lima Commercial Cluster
}

\author{
Singgih Hartanto*, Soegiono Soetomo, Broto Sunaryo, Wisnu Pradoto \\ Architecture and Urban Planning Department, Diponegoro University, 1269, Semarang, Indonesia
}

Received February 9, 2020; Revised May 14, 2020; Accepted May 20, 2020

Copyright $\bigcirc 2020$ by authors, all rights reserved. Authors agree that this article remains permanently open access under the terms of the Creative Commons Attribution License 4.0 International License

\begin{abstract}
Compact city emerged as one of the concepts that opposed the concept of urban sprawl. Its primary objective relied on the greater densification of spatial use under the term called mix land-use to reduce energy consumption on mobility. Our article intended to delve into a study which relates electricity to Compact city. The focus is to quantitatively analyze the interdependence between Compact city and electricity efficiencies. Simpang Lima central business district (CBD) in Semarang city constituted the field study. This article employs positivistic approach that consists of cross-analyzing GIS-Nearest Neighbor analysis dedicated for spatial buffering analysis and ETAP technique devoted to calculating energy losses within the CBD cluster. Our findings imply such a primary hypothesis that the distribution of the buildings on a cluster that covered by the electricity supply from central substation positively affected the distribution efficiencies. A group of commercial building with minimum distance of $129.49 \mathrm{~m}$ among them in a cluster of $1,424.6$ Ha poses an ability to save more than $0,293 \%(11.411 / \mathrm{Kwh})$ compared to another cluster. Thus, this research is a preliminary discussion that aims at enriching Compact city discussion by bringing forth the electricity sector as a considerable aspect.
\end{abstract}

Keywords Compact City, Cluster, Electricity, Distribution Distance

\section{Introduction}

The Compact city concept proposed a paradigm of mix-use spatial organization in which a greater energy efficiency could be attained in favor of cluster density formula (Ellis, Dantzig, \& Saaty, 1975). The implementation of compact city also has clear connection with the government policy, the current of urbanization to the sector of transportation and energy consumption including its emissions. Energy efficiency within this type of city is able to be achieved by some innovation on urban planning rules by optimizing the city size and its characteristics (Lee \& Lim, 2018). The planning of the ideal and sustainable urban in the green and compact city through eco-friendly infrastructure and land mixing have become the trending by the purpose to have efficient and safe frame area. By the perspective of poverty in the field of energy, this city brings solution through combining the development policy, strategies on sustainability, and the use of energy. Socioeconomic factors covering its location and the standard of used households, are the potential and significant contributors on reducing the energy consumption (Mrowczynska\&Sztubecka, 2020). It leads to a balance key of urban living and development for sustainable and lively city in a global urban form (Tappert\& Drilling, 2018). The balance maintenance on reducing green- house effects and preventing due to the lost on urban development is also advisable on reducing the energy usage by the planning on compact city (Xu \& Yang, 2019). The uncontrolled on the massive development on urban area comes to the sprawled and complicated city. It is needed a city platform that enables the urban sustainability form by optimizing green and compact cities visions. The concept in its city is achieved through the combination framework on the growth limit, the infrastructure development and nature preservation (Artmann\& Loja, 2019). The paradigm on compact city also includes the attribute that helps to figure out the consumption on energy, gas emissions, travel distances and the infrastructure length (Angel \&Blei, 2018). Compact City also emerged as one of the concepts that opposed to the phenomena of urban sprawl to which embedded the caveats of higher energy consumption (Dieleman \& Wegener, 2004; Neuman, 2005). Understanding the role of the built environment in subjective well-being (SWB) can provide important input to urban planning (Mouratidis, 2019). The scientific 
discoveries of recent decades and in particular those relating to complexity theory have led the city as a typical example of adaptive complex system (Chirianni, 2017). For numbers of authors Compact city rather offers an ambitious regards to save more energy by limiting people mobility as a product of urban form dynamics which creates distance between one activity to another (Priemus, Nijkamp, \& Banister, 2001). Indispensable significance for laying line structures of technical infrastructure determines the operational function of buildings and their sets (Kubečková\&Kročová, 2019).

Beyond the expectation to optimize spatial cluster through mix-use activities, mobility sectors are central to compact city (Boussauw, Neutens, \& Witlox, 2012). In the metropolitan area, it is definitely applicable to have the planning on compact city. It includes planning policies and the patterns on travelling (Lee \& Kim, 2017). Reducing the sprawl and increasing the life quality are encouraged by a compact city by some efforts on sustainability urban planning such as using tax- generation and vacant's redevelopment (Pearsall, 2017). In the compact city, there is also relationship between the pattern on commuting and the form or urban that brings to efficiency. On the other hand, it attractes more workers to come by the existence of sub centers in new suburban (Jun, 2020). It is characterized by compatibility for solutions towards cities problems and population densities (Chen \& Lau, 2008). The compact city theory was first coined by Dantzig and Saaty in 1973, and this theory was not conceived only to save energy consumption but was further used to ensure the sustainability (Saaty, 1973). In this theory there is a very strong relationship between spatial patterns, the shape of cities and sustainable development. There are three main aspects in Compact city theory: form of spaces, space characteristics and functions (Saaty, 1973). The table below overview the three aspects:

Table 1. The three aspect of Compact City (Ibid, 1973)

\begin{tabular}{|c|c|c|}
\hline $\begin{array}{c}\text { Form } \\
\text { of Spaces }\end{array}$ & $\begin{array}{l}1 . \\
2 .\end{array}$ & $\begin{array}{l}\text { High dense settlement } \\
\text { Less dependence of automobile (High } \\
\text { density) } \\
\text { Clear boundary from surrounding area }\end{array}$ \\
\hline $\begin{array}{c}\text { Space } \\
\text { Characteristic }\end{array}$ & $\begin{array}{l}4 . \\
5 . \\
6 .\end{array}$ & $\begin{array}{l}\text { Mixed land use } \\
\text { Diversity of life (Complex land use) } \\
\text { Clear Identity }\end{array}$ \\
\hline Function & $\begin{array}{l}7 . \\
8 . \\
9 .\end{array}$ & $\begin{array}{l}\text { Social fairness (high dense settlement) } \\
\text { Self-sufficiency of daily life } \\
\begin{array}{l}\text { Independency of governance (clear } \\
\text { boundary) }\end{array}\end{array}$ \\
\hline
\end{tabular}

Understanding the concept of compact city, it was agreed implicitly that criticism of the urban sprawl phenomenon became the basis. Definitively, urban sprawl is usually indicated by the presence of low density, leapfrog distribution and with elongated characters following the path. Urban sprawl is characterized by two main indicators, a considerable distance between residential to other activities and open space deficiency
(Daneshpour \& Shakibamanesh, 2011). Meanwhile, other authors debate that urban sprawl is a form of unplanned city, uncontrolled, and uncoordinated character with a single land use detached to the surrounding area. Sprawl has a strong impact on cost, social and environmental issues and represents an urban spectrum that is skewed to the basic pattern of inefficiency (Nelson \& Sanchez, 2005). Some locations were eventually fragmented, breaking both its physical structure as its social and cultural dynamics (Altieri\& Rojas, 2016).

However, beyond the stress on urban form, mix-use urban pattern and efficiency in mobility, other energy sector such as electricity is yet to be primordial within the approach of compact city. Numerous academic research and official report from national energy agency such as U.S. Department of Energy suggested not only a strong correlation between compact city concept and transport but also for electricity efficiency by reducing losses (Oak Ridge National laboratory report 2015). Under such perspective, a high density cluster form with certain distance grid distribution among buildings could theoretically reduce energy losses as electricity efficiency relied on the percentage of energy losses (Bataineh \& Alrabee, 2018; Ewing \& Rong, 2008).

Despite the fundamental conception proposed within the compact city theory, conceptualizing cities energy efficiency israther a complex task with the rise of plentiful ideas against city energy ineffectiveness such as renewable energy concept (Keirstead, 2013), or the recent one : smart grid (Kloppenburg \& Boekelo, 2019; Mah, Wu, Ip, \& Hills, 2013), green buildings (Uddin, Selvam, Shahoonda, \&Prasanth, 2018), block chain energy concept (Andoni et al., 2019) and notably the increasing use of information technology and data processing to monitor urban planning process (Hasler, Chenal, \& Soutter, 2017). Occupant characteristics have significant impact on electricity consumption in residential building (Xu, Xiao, \& Li, 2020). On his book published in 2010, James Keirstead advocated a hypothesis of a low energy urban layout that coherent to the concept of compact city. This study exemplified that residential density could reduce the significantly the needs for heater during some period, resulting in a major energy savings of $31 \%$ and carbon gas by $33 \%$. In contrast, in the case of sparse layouts, the construction of large houses in sparse low-density layouts increases this heat loss, leading to an increase in energy and primary carbon of $34 \%$ and $27 \%$. Then Keirstead also explains the difference in the transportation sector, which see an energy savings of $24 \%$ in a compact case and an increase of $51 \%$ in a sparse layout (Keirstead, Jennings, \& Sivakumar, 2012).

While the discussion of city energy efficiency in many European countries has entered various new domain, many urban and regional researchers acknowledge that for many cities in developing countries, an approach toward energy efficiency is still lounging on urban form and energy losses. As emphasized by Ibrahim (2014), most of developing 
countries such as Indonesia, has reached $20 \%$ energy losses (in developed countries the losses are set on 3 to $6 \%$ losses while in developing countries the ideal number should not exceed $10 \%$ losses) due to the length of the network, the location of the source of electric energy distribution model and location of the building. The uncontrolled and unplanned urban patterns contribute massively to energy losses (Ibrahim, 2014), Mahmood et al., 2014).

Whereas, so far, there exists a poor percentage of scientific research aimed at investigating the electricity losses of on uncontrolled and unplanned urban forms. Bearing with this condition, we would like to bring forward this research with focus on the relation of land use pattern, building location in a commercial cluster composed by the commercial building par excellence such as mall, hotels, department store, banks etc. to provide a quantitative measure of the relation between electricity losses and spatial arrangement notably the building's location towards central electricity feeder. It then raises a question according to the concept of Compact city: does the distribution model of building within a commercial cluster could positively reduce energy losses? Thus, under such circumstance, this article would like to offer a quantitative analysis regarding the electricity losses in Simpang Lima central business district in Semarang city.

As for our field study, the city of Semarang as the Capital of Central Java Province certainly presents a variety of land uses. Ranging from settlements, housing, trade, services to industry. The location of this study will be detailed in 4 types of patterns, namely Settlements, Trade and Services, and Industry. Furthermore, to select the study area per pattern type, a remote sensing data were used which was then overlaid with the substation feeder service area data from the PLN (Indonesian state utility company) in order to determine the delineation of our locus.
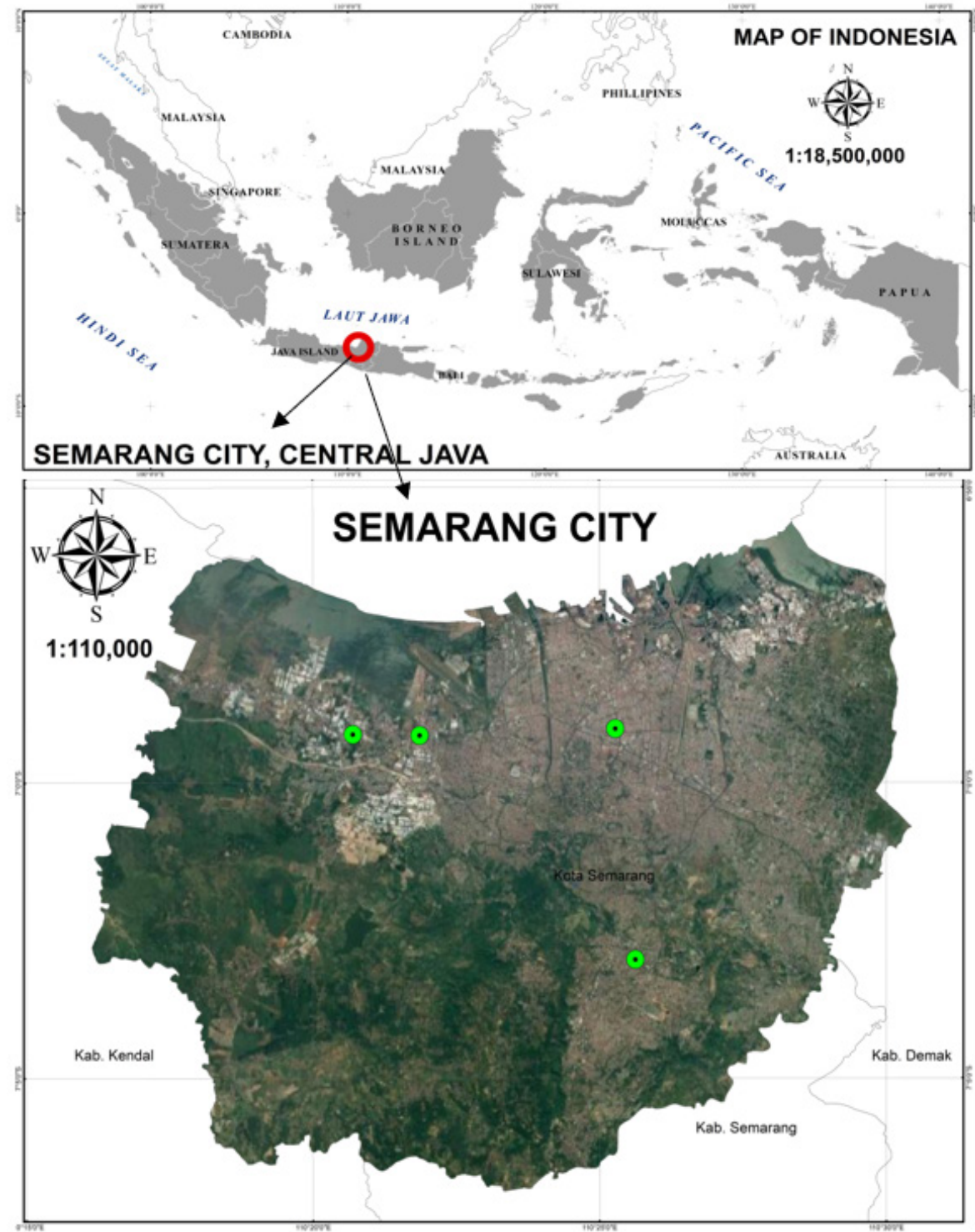

Figure 1. Four main electricity feeder in Semarang City 
Based on the map above and the results of the remote sensing process and by looking at the percentage of electricity consumption, we then figure among four principal feeder in Semarang, and the $\mathrm{GI}^{1}$ of Simpang Lima CBD has the most significant quantity of business and services activity.

Table 2. Four Principles of Power Sub-station Electricity in Semarang

\begin{tabular}{|c|c|c|c|c|c|}
\hline \multirow[b]{2}{*}{ No } & \multirow[b]{2}{*}{$\begin{array}{l}\text { Sub Station Powers' } \\
\text { Name }\end{array}$} & \multirow[b]{2}{*}{ Pattern } & \multicolumn{3}{|c|}{ Electricity Consumption } \\
\hline & & & $\begin{array}{c}\text { Business } \\
\text { and } \\
\text { services }\end{array}$ & Residential & Industries \\
\hline 1 & $\begin{array}{c}\text { Krapyak Main Electricity } \\
\text { Feeder }\end{array}$ & \multirow{2}{*}{ Industries } & 0.33 & 0.00 & 99.67 \\
\hline 2 & $\begin{array}{l}\text { Randugarut Main } \\
\text { Electricity Feeder } \\
\end{array}$ & & 1.45 & 2.42 & 96.12 \\
\hline 3 & $\begin{array}{c}\text { Simpang Lima Main } \\
\text { Electricity Feeder }\end{array}$ & Business & 80 & 17 & 3 \\
\hline 4 & $\begin{array}{c}\text { Srondol Electricity Main } \\
\text { Feeder }\end{array}$ & $\begin{array}{c}\text { Housing and } \\
\text { residential }\end{array}$ & 31 & 68 & 1 \\
\hline
\end{tabular}

Beyond the electricity data consumption, this research identifies the losses factor between four different patterns in order to justify more specifically the research perimeter. In terms of losses distribution, the CBD Simpang Lima possess the lowest rated electricity losses as shown by the picture below. The losses factor justified to choose of Simpang Lima as field of observation by virtue of its efficiency in energy consumption.

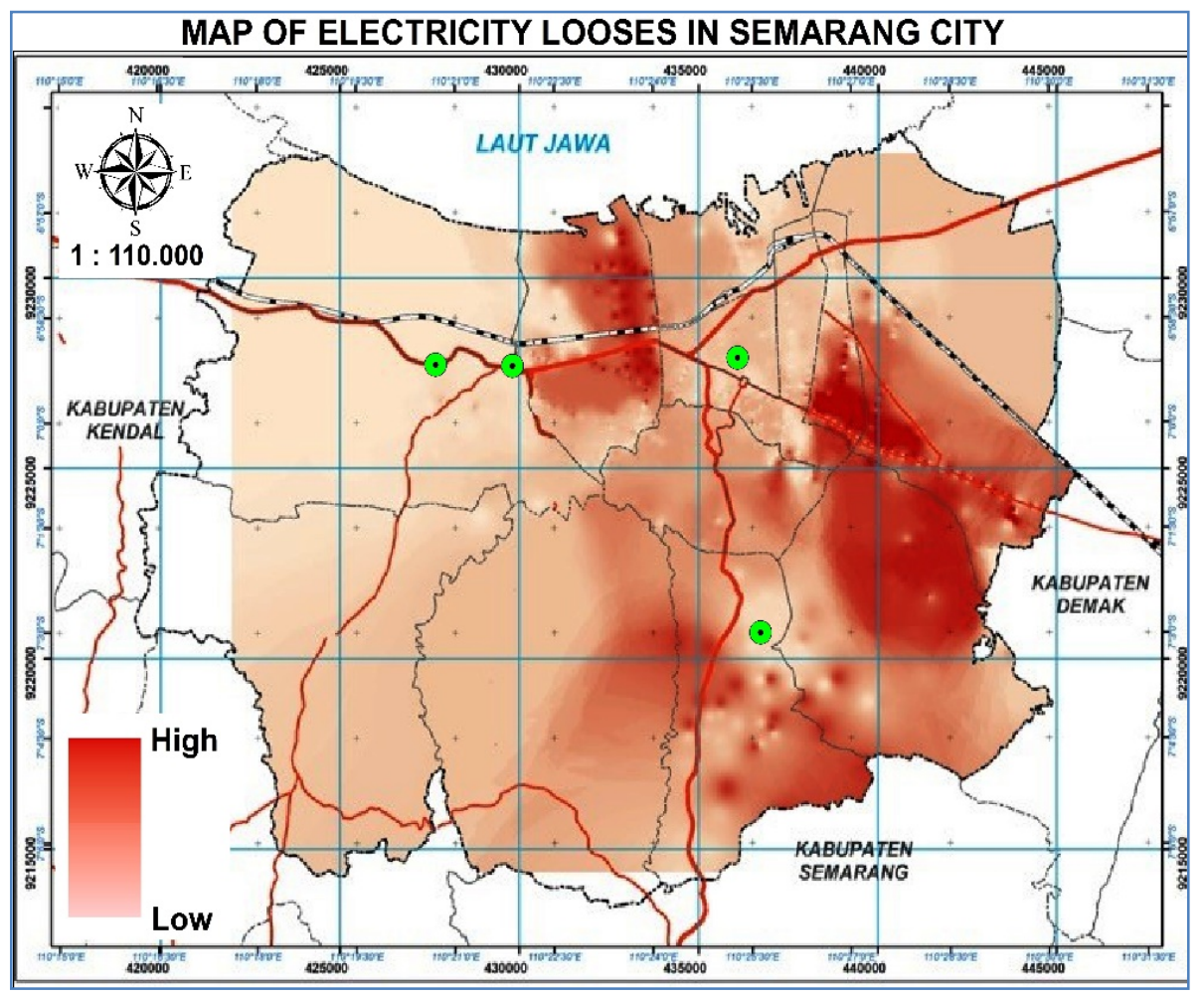

Figure 2. Electricity losses among four feeders. Red color identifies the highest losses 
The specific profile of Simpang Lima as the biggest CBD in Central Java Province, home to numbers of business activity buildings that comfort its highly rated status as an important place in terms of economic point of view. Financial services, mal and department stores, hotels, insurances, schools, university, public government services are concentrated densely at Simpang Lima. With the highest form of activity combination at one place, it suggests that Simpang Lima could well represent a mix land-use compared to other part of the city of Semarang which is relevant to a compact city ideas (FOORD, 2010). By the background from the preliminary and literature study mentioned above, this study has a purpose to find out the relation between the energy loses for consumption and location of compact city.

\section{Materials and Methods}

Research data is divided into two primary data and secondary data. Primary data is consisted by data sources of energy (Mains Substation/GI) that serves commercial buildings. Total power capacity of the Simpang Lima main Substation (GI) is 120 MVA transformer with 2 pieces each of 60 MVA and with 13 feeder (SPL). While secondary data is data the electrical load is obtained from the PLN. Primary data retrieval is collected since 2016 with the sampling method using Global Positioning System (GPS). There are three variables used in this study i.e.

- Free variables : point location of buildings (trade), the load of the electric energy consumption

- Variables bound : the location of Mains Substation

- Control variables : Distance or Long network and losses.

Within this cluster that subject to buffer processes, central electricity feeder of GI Simpang Lima serves around thousands of major businesses buildings in different area of businesses activities. The consumption amount of a single building reached between 200.000VA to $500.000 \mathrm{VA}$.

To measure the efficiency rate of Simpang Lima feeder, two forms of analysis are presented: (1) spatial analysis which encompassed buffer analysis to delineate the cluster characteristic according to Compact city theory and which is also determined by the grid coverage of Simpang Lima feeder. This cluster perimeter could facilitate our understanding of a specified zone with specific spatial data features(Bhatia, Vira, Choksi, \& Venkatachalam, 2013) in our cases, the spatial data features are the distribution point of building served by GI Simpang Lima within the cluster. (2) the second form of analysis is ETAP program devoted to quantify the electricity losses within the given cluster.

Analysis of the distribution point of the building using the Nearest Neighbor analysis (ANN) will show the pattern of distribution building points location based on the calculation of the distance, the number of point locations and territories (Chopade \& Bikdash, 2011). Results or output of the Analysis is the Neighbor Nears the Z-Score and index P-Value that indicates whether a region shaped clusters, random or dispersed (Dixon, 2002). There are three scale of Nearest Neighbor i.e.

- ANN : 1 random.

- ANN < 1 cluster

- $\quad$ ANN > 1dispersed

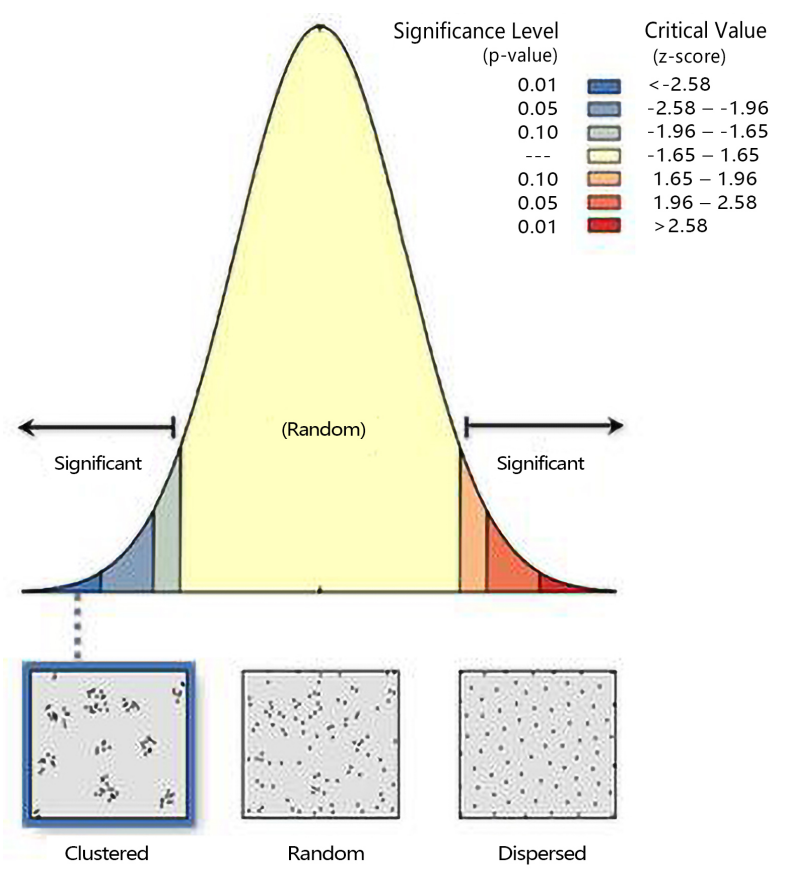

Figure 3. Diagram Nearest Neighbor Analysis

- The buffer is used to determine the limits of the furthest point location distribution service area

- Regression analysis for estimation number of points

This projection with linear regression equation to model the relationship between load, $\mathrm{Z}$ score, buffer, and the distance of the point that produces the number of point locations. This relationship model equations can be written as follows:

$$
\begin{gathered}
\mathrm{Y}=0,1394903+0,0073084 \cdot \mathrm{X}_{1}+-0,0000001 \cdot \mathrm{X}_{2}+ \\
0,0094375 \cdot \mathrm{X}_{3}+0,0221952 \cdot \mathrm{X}_{4}
\end{gathered}
$$

Information :

$\mathrm{Y}=$ distance between points

$\mathrm{X}_{1}=\mathrm{Z}$ score parameter

$\mathrm{X}_{2}=$ load parameter

$\mathrm{X}_{3}=$ number of points parameter

$\mathrm{X}_{4}=$ buffer parameter

Based on the obtained model value R square of 0.6982 .

- $\quad$ ETAP program is employed to calculate the losses that is stated in\% (percent). The larger the value of losses the bigger the inefficiency of the electricity distribution. 


\section{Results and Discussions}

The findings of the analysis are allowed to compare the existing conditions which is unplanned buildings distribution point at Simpang Lima and the projection of efficient building distribution with highest possibility to lower the electricity losses in the given cluster.

Figure 4 shows the results of measurements and calculations on the existing conditions of the distribution of electrical energy in the area of Simpang Lima Semarang city. On the conditions of the existing distribution point location pattern of this building in the commercial district is a cluster with a distance of $3200 \mathrm{~m}$ buffer. From the existing conditions is known that the value of the Z-score and average distance and loses in the commercial area is 4.722555-z (cluster) average distance of $140 \mathrm{~m}$ and losses with a total load of $1.3697 \% 29,25 \mathrm{MVA}$ and 104-point location of the building.

Figure 4 signals the result of projection model from the existing conditions. This modelling needs for commercial load on the map out in advance be 32.75 MVA, then counted the number of additions the point location of the building and put the distribution point location of the building on the farthest distance but still in the buffer. Calculated average distance and the nearest neighbor analysis with losses and ETAP. From the results of this modeling is obtained that the distribution point location building still cluster with the value of the z-score: -1.761257 with a distance of average $170 \mathrm{~m}$. and losses $1.6730 \%$.

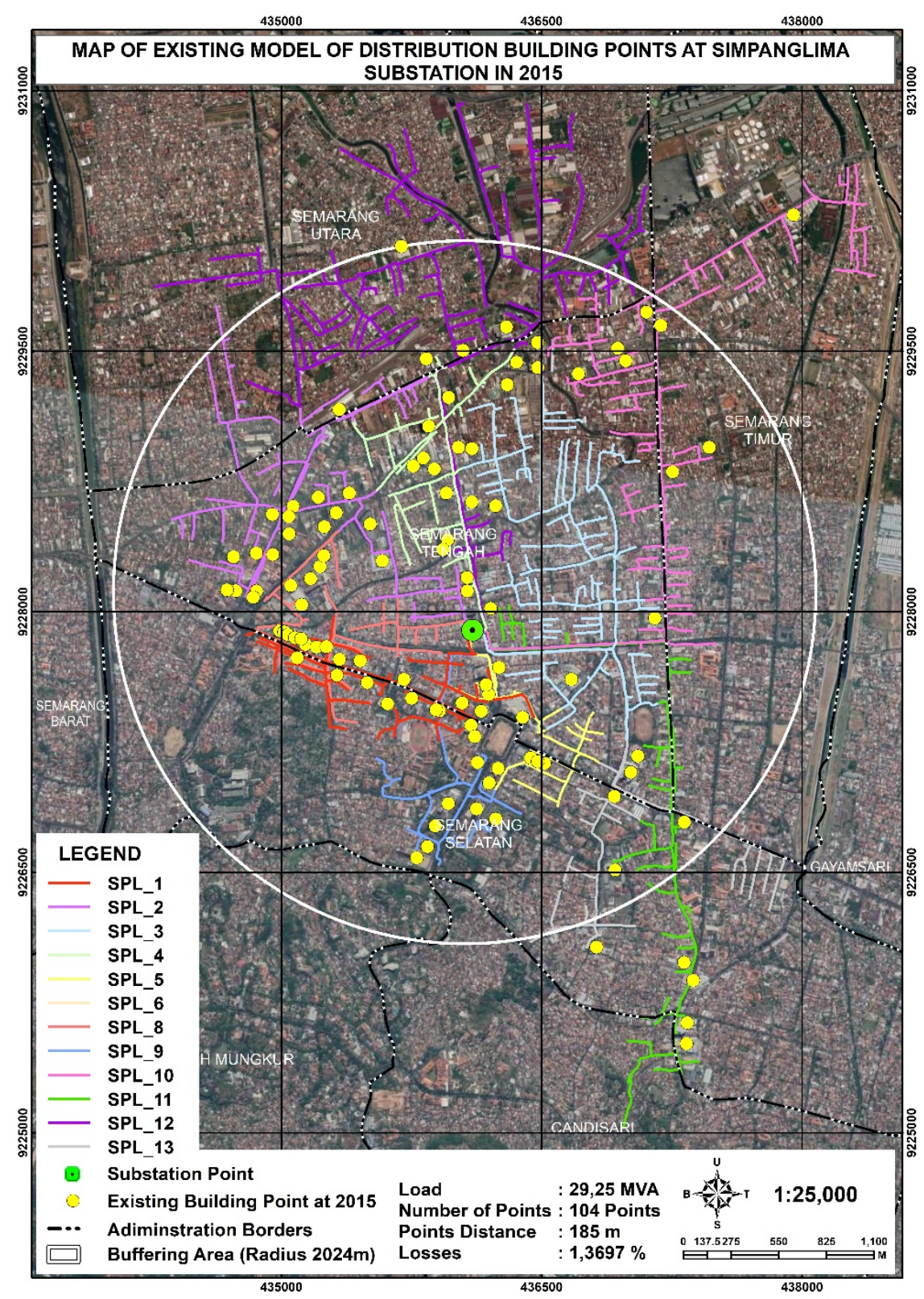

Figure4. Existing model of Simpang Lima cluster, average distance and its losses rate 
Table 4. Results of Average Nearest Neighbor analysis, Losses in existing and projection Model

\begin{tabular}{cccccc}
\hline $\begin{array}{c}\text { Distribution } \\
\text { Building } \\
\text { location }\end{array}$ & LoadMVA & $\begin{array}{c}\text { Number } \\
\text { of points }\end{array}$ & $\begin{array}{c}\text { Average } \\
\text { distance } \\
\text { between } \\
\text { points } \\
\text { (ANN) }\end{array}$ & $\begin{array}{c}\text { Final Z } \\
\text { score }\end{array}$ & $\begin{array}{c}\text { PresentLosses } \\
(\%)\end{array}$ \\
\hline Existing & $29,25 \mathrm{MVA}$ & 104 & $\begin{array}{c}140 \mathrm{~m} \\
\text { (compact) }\end{array}$ & $\begin{array}{c}-4.722555 \\
\text { (cluster) }\end{array}$ & $1,3697 \%$ \\
\hline $\begin{array}{c}\text { Projection } \\
\text { model }\end{array}$ & 32.75 MVA & 125 & $\begin{array}{c}170 \mathrm{~m} \\
\text { (Compact) }\end{array}$ & $\begin{array}{c}-1.761257 \\
\text { (cluster) }\end{array}$ & $1,6730 \%$ \\
\hline
\end{tabular}

\section{A}

B

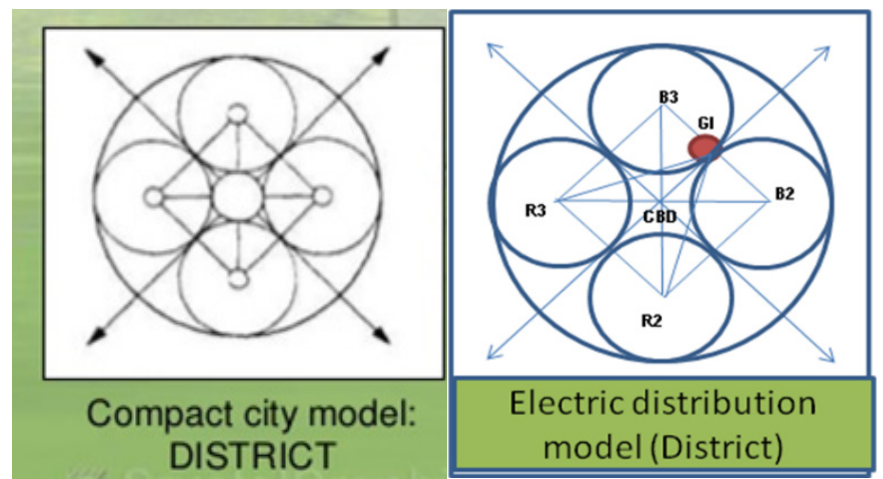

Figure 5. Comparison of Compact City model of Dantzig \& Saaty (A) and finding (B)

According to this analysis, in order to Simpang Lima central feeder to reach its optimum carrying capacity, the compact city ideas are relevant to in the coming years, the cluster could still serve dozens of new building with electricity consumption rate between 100.KVA to 500 KVA.

By comparing the results of calculations on existing conditions and conditions after the simulation modeling in the distribution pattern, it is estimated that in order to reach the optimal efficiency, and the density of the building's location under the circumstance of the Compact city is relevant to increase energy efficiency in Simpang Lima CBD. The research figures out the projection model could reduce the energy losses in the estimate of equivalent to $0.31 \%(7,392 / \mathrm{Kwh})$.

\section{Conclusions}

It can be concluded that the model the location of buildings (banks, malls, hotels, office space, educational etc) in the commercial cluster become one of the variables that needs to be deeply considered in city planning process in favor of efficiency in distribution system electrical energy. By calculating the average distance point location with Nearest Neighbor Analysis leads to reveal that cluster form is more efficient. Case study on this commercial district can answer the questions of the commercial buildings location which contribute to electricity efficiency and can probably the example of Compact cluster commercial.

From the perspective of Compact city theory advanced by Dantzig and Saaty, it is assumed that a solid model of buildings and energy efficiency has not been furtherly developed. Thus, this research aware about the transport and mobility aspect are central in Compact city theory. Through this study, it proposes that reducing electricity losses within the grid on a given cluster could be fruitful to enlarge the discussion of Compact city, notably in major city in Indonesia where the city still relied on the traditional electricity distribution grid. The findings stressed out on densifying the commercial building within the cluster. To grasp the realm of the dynamic of Simpang Lima CBD, this research proposes the projection of the future building location to be situated within the buffer in order to reach the optimum less energy losses. This research recognized the limit of technical resolution that being confronted with the abundance of aspect such as socio-political economy of commercial building location, however the preliminary quantitative resolution of electricity efficiency in a cluster under the concern of Compact city theory should offer a technical understanding. The needs to integrate between land-use planning and energy planning in the future development of Simpang Lima CBD is crucial. The dialogue between land use and electricity sector should from now on be considered as interdependent aspect. 


\section{Acknowledgements}

We are very grateful to say our thankfulness to Architecture and Urban Planning Department, Diponegoro University and the stakeholders of Semarang city which were willing to cooperate in completing this research. We also want to say our gratitude for all those who have helped both material and moral so that this research can be carried out well.

\section{REFERENCES}

[1] A. C. Nelson, \& T. W. Sanchez. The effectiveness of urban containment regimes in reducing exurban sprawl. DISP. 41(60), 42-47, 2005.

[2] A. Daneshpour, \& A. Shakibamanesh. Compact city; dose it create an obligatory context for urban sustainability? International Journal of Architectural Engineering \& Urban Planning, 2011.

[3] A. Marcello \& R. Rodrigo. Urban Fragmentation and Discontinuity: Paranhos Case Study. Horizon Research Publishing Corporation. Civil Engineering and Architecture.175-182, 2016.

[4] C. Claudia. City as Open Work. Horizon Research Publishing Corporation. Civil Engineering and Architecture. 66-70, 2017.

[5] C. Xu\& Z. Yang. The impact of urbam compactness on energy-related greenhouse gas emissions across EU member states: population density vs physical compactness. Applied Energy. 254, 113671, 2019.

[6] D. Kubečková\& S. Kročová. University Campuses of Public Space and Subject of Architectural Design and Related Technical Infrastructure. Horizon Research Publishing Corporation. Civil Engineering and Architecture. 262-270, 2019.

[7] D. N. Mah, W. Yin, Y. Y. IP, J. C. man, \& P. R. Hills. The role of the state in sustainable energy transitions: A case study of large smart grid demonstration projects in Japan. Energy Policy, 2013.

[8] F. Dieleman, \& M. Wegener. Compact city and urban sprawl. Built Environment. 30(4), 308-323, 2004.

[9] H. Chen \& S. S. Y. Lau. Sustainable urban form for Chinese compact cities: challenges of a rapid urbanized economy. Habit International. 32(1), 28-40, 2008.

[10] H. D. Ibrahim. Energi Selamatkan Negeri. Jakarta: The Indonesian Reform Institute, 2014.

[11] H. Priemus, P. Nijkamp, \& D. Banister. Mobility and spatial dynamics: An uneasy relationship. Journal of Transport Geography. 9(3), 167-171, 2001.

[12] H. Pearsall. Staying cool in the compact city: vacant land and urban heating in Philadelphia, Pennsylvania. Applied Geography. 79, 84-92, 2017.

[13] J. H. Lee \& S. Lim. The selection of compact city policy instruments and their effects on energy consumption and greenhouse gas emissions in the transportation sector: the case of South Korea. Sustainanle Cities and Societ. 37, 116-124, 2018.

[14] J. Keirstead. Benchmarking urban energy efficiency in the UK. Energy Policy. Keirstead, J., Jennings, M., \& Sivakumar, A. (2012). A review of urban energy system models: Approaches, challenges and opportunities. Renewable and Sustainable Energy Reviews. 63(C), 575-587, 2013.

[15] K. Bataineh, \& A. Alrabee, A. (2018). Improving the energy efficiency of the residential buildings in Jordan. Buildings, 2018.

[16] K. Boussauw, T. Neutens, T., \& Witlox, F. (2012) Relationship between Spatial Proximity and Travel-to-Work Distance: The Effect of the Compact City. Regional Studies. 4(6), 687-706, 2012.

[17] K. Mouratidis. Compact City, Urban Sprawl, and Subjective well-being. The International Journal of Urban Policy and Planning. 261-272, 2019.

[18] M. Andoni, V. Robu, D. Flynn, S. Abram, D. Geach, D. Jenkins, A. Peacock. Blockchain technology in the energy sector: A systematic review of challenges and opportunities. Renewable and Sustainable Energy Reviews. 100 (2), 143-174, 2019.

[19] M. Artmann\& L. C. Loja. How smart growth and green infrastructure can mutually support each other- a conceptual framework for compact and green cities. Ecological Indicators. 96(2), 10-22, 2019

[20] M. J. Jun. The effects of polycentric evolution on commute times in a polycentric compact city: A case of the Seoul metropolitan area. Cities. 98, 102587, 2020.

[21] M. Mrowczynksa\& M. Sztubecka. Household standard and socio-economic aspects as a factor determining energy consumption in the city. Applied Energy. 264, 114680 , 2020 .

[22] M. Neuman. The compact city fallacy. Journal of Planning Education and Research. 122(1), 58-62, 2005.

[23] M. Uddin, N. A. M. Selvam, J. Shahoonda, \& R. Prasanth, R. Optimization of green building for low-income people at pondicherry. Civil Engineering and Architecture. 6(6), 283-292, 2018.

[24] P. Chopade, \& M. Bikdash, M. Minimizing cost and power loss by optimal placement of capacitor using ETAP. 2011 IEEE 43rd Southeastern Symposium on System Theory, 24-29, 2011.

[25] P. M. Dixon. Nearest-neighbor contingency table analysis of spatial segregation for several species. Écoscience, 9(2), 142-151, 2002.

[26] R. Ewing, \& F. Rong. The impact of urban form on U.S. residential energy use. Housing Policy Debate. FOORD, J. O. (2010). Mixed-Use Trade-Offs: How to Live and Work in a "Compact City" Neighbourhood. Built Environment (1978-), 36(1), 47-62, 2008.

[27] S. Angel \& A. M. Blei. The shape compactness of urban footprints. Progress in planning. 2018. 
[28] S. Bhatia, V. Vira, D. Choksi, \& P. Venkatachalam. An algorithm for generating geometric buffers for vector feature layers. Geo-Spatial Information Science, 16(2), 130-138, 2013.

[29] S. Hasler, J. Chenal, \& M. Soutter. Digital Tools as a Means to Foster Inclusive, Data-informed Urban Planning. Civil Engineering and Architecture. 5(6), 230-239, 2017.

[30] S. Kloppenburg, \& M. Boekelo. Digital platforms and the future of energy provisioning: Promises and perils for the next phase of the energy transition. Energy Research and Social Science. 49, 68-73, 2019.

[31] S. Lee \& K. Kim. Relationship between transit modal split and intra-city trip radio by car for compact city palnning of municipalities in the Seoul metropolitan area. Cities. 70, 11-21, 2017.

[32] S. Tappert \& M. Drilling. Contested urban green spaces in the compact city: the (re-)negotiation of urban gardening in Swiss cities. Landscape and Urban Planning. 170, 69-78, 2018.

[33] W. R. Ellis, G. B. Dantzig., \& T. L. Saaty. Compact City: A Plan for a Liveable Urban Environment. Contemporary Sociology. 4(4), 447-448, 1975.

[34] X. Xiaoxiao, X. Bing, \&, L. Z. Clyde. Critical Factors of Electricity Consumption in Residential Building: An Analysis from the Point of Occupant Characteristics View. Journal of Clearner Production, 2020. 